\title{
Somatic mutations of the thyroid-stimulating hormone receptor gene in feline hyperthyroidism: parallels with human hyperthyroidism
}

\author{
S G Watson, A D Radford, A Kipar ${ }^{1}$, P Ibarrola and L Blackwood \\ Small Animal Hospital, Department of Veterinary Clinical Science, University of Liverpool, Crown Street, Liverpool, Merseyside L7 7EX, UK \\ ${ }^{1}$ Department of Veterinary Pathology, University of Liverpool, Crown Street, Liverpool, Merseyside L69 7ZJ, UK \\ (Requests for offprints should be addressed to L Blackwood; Email: L.Blackwood@liverpool.ac.uk)
}

\begin{abstract}
Hyperthyroidism is the most common endocrinopathy in cats, and is both clinically and histopathologically very similar to human toxic nodular goitre (TNG). Molecular studies on human TNG have revealed the presence of mis-sense mutations in the thyroid-stimulating hormone receptor (TSHR) gene, most frequently in exon 10. Our hypothesis was that similar mutations exist in hyperthyroid cats. Genomic DNA was extracted from 134 hyperplastic/ adenomatous nodules (from 50 hyperthyroid cats), and analysed for the presence of mutations in exon 10 of the TSHR gene. 11 different mutations were detected, one silent and 10 mis-sense, of which nine were somatic mutations. 28 of the 50 cats $(67 / 134$ nodules) had at least one mis-sense mutation. The mis-sense mutations were Met-452 $\rightarrow$ Thr in 17 cats (35 nodules), Ser-504 $\rightarrow$ Arg
\end{abstract}

(two different mutational forms) in two cats (two nodules), Val-508 $\rightarrow$ Arg in one cat (three nodules), Arg-530 $\rightarrow$ Gln in one cat (two nodules), Val-557 $\rightarrow$ Leu in 13 cats (36 nodules), Thr-631 $\rightarrow$ Ala or Thr-631 $\rightarrow$ Phe (each mutation seen in one nodule of one cat), Asp-632 $\rightarrow$ Tyr in six cats (10 nodules) and Asp-632 $\rightarrow$ His in one cat (one nodule). Five of these mutations have been associated previously with human hyperthyroidism. Of the 41 cats for which more than one nodule was available, 14 had nodules with different mutations. The identification of a potential genetic basis for feline hyperthyroidism is novel, increases our understanding of the pathogenesis of this significant feline disease, and confirms its similarity to TNG.

Journal of Endocrinology (2005) 186, 523-537

\section{Introduction}

Feline hyperthyroidism (FH) is a very common endocrine condition, resulting in debilitating disease in a significant percentage of middle-aged and older cats (Holzworth et al. 1980, Hoenig et al. 1982, Peterson et al. 1983, Thoday \& Mooney 1992, Peterson et al. 1994). It is analogous, clinically and pathologically, to toxic nodular goitre (TNG) in elderly humans, although in cats there is no sex predisposition (Peterson \& Becker et al. 1983, Peter et al. 1985, Capen 2002). In both species, hyperthyroidism is caused by thyroid-stimulating hormone (TSH)independent overactivity of one or more benign hyperfunctioning adenomatous thyroid nodules (Peterson et al. 1994). This results in high circulating concentrations of thyroxine $\left(\mathrm{T}_{4}\right)$ and tri-iodothyronine $\left(\mathrm{T}_{3}\right)$ hormones (Thoday \& Mooney 1992), which cause multisystemic clinical signs including weight loss, increased appetite, tachycardia and polyphagia (Peterson et al. 1983, Capen 2002). In both species, thyroid carcinoma is a rare cause of hyperthyroidism (Leav et al. 1976, Holzworth et al. 1980,
Hoenig et al. 1982, Capen 2002, Hegedus 2004, Pacini et al. 2004).

The aetiopathogenesis of FH and TNG is complex and multifactorial, and is not fully elucidated. However, numerous studies have identified genetic lesions within key components of the TSH receptor (TSHR) signalling pathway in human TNG (Tonacchera et al. 2000, Yen et al. 2000, Corvilain et al. 2001, Kopp 2001). Most mutations have been identified in the TSHR gene, with up to $82 \%$ of cases of human TNG having identifiable TSHR mutations (Parma et al. 1997). These mutations are generally within exon 10 of the TSHR gene, specifically within the transmembrane domain, and a 'hot spot' for gain-of-function mutations has been identified at amino acids 619-650 (Yen et al. 2000, Kopp 2001).

The feline and human TSHR are very similar at both genetic and functional levels (Nguyen et al. 2002). However, few studies have investigated the prevalence of TSHR mutations in cats (Pearce et al. 1997, Nguyen et al. 2002, Peeters et al. 2002), and only one study has detected an exon 10 TSHR transmembrane mis-sense 
mutation, in vitro, in one thyroid cell line (Nguyen et al. 2002). However, some studies have only looked at part of the TSHR gene, excluding areas where mutations have been reported in the human condition (Pearce et al. 1997, Peeters et al. 2002), and only a small number of samples have been investigated (Pearce et al. 1997, Nguyen et al. 2002, Peeters et al. 2002). More importantly, investigators have not attempted to detect mutations in individual nodules (Pearce et al. 1997, Peeters et al. 2002). Hyperplastic nodules are surrounded by apparently normal paranodular thyroid tissue (Ferguson et al. 1990), and therefore DNA extracted from the whole thyroid lobe will represent both diseased and normal tissue, the latter causing dilution of the diseased tissue DNA, potentially masking any mutations. In addition, different mutations have been found in different nodules taken from individual human thyroid glands (Fuhrer et al. 1996, Holzapfel et al. 1997a, Duprez et al. 1997a, Parma et al. 1997, Tonacchera et al. 1998a, 2000, Fuhrer et al. 2003), and such mutations would also be masked by extraction of DNA from whole thyroid lobes.

In this study, we investigated the prevalence of mutations in the TSHR gene in individual nodules from cats with thyroid nodular adenomatous hyperplasia and/or thyroid adenomas.

\section{Materials and methods}

\section{Sample recruitment}

Formalin-fixed thyroid lobes were obtained after therapeutic thyroidectomy from cats with $\mathrm{FH}$ (confirmed by elevated resting total thyroxine $\left(3,5,3^{1}, 5^{1}\right.$-tetraiodothyronine) concentrations in plasma or serum, and compatible histopathological findings), from veterinary surgeons throughout the UK. Samples were sequentially assigned a $\mathrm{T}$ number upon arrival in the laboratory. Bilateral lobes were designated A and B. Individual nodules were identified by gross examination of each affected lobe, and numbered sequentially. Each thyroid lobe was cut in half so that all identified nodules were bisected. One half of the lobe was submitted for histopathological evaluation, to identify the type of lesion and its compatibility with FH (Capen 2002). The bisected nodules in the other half of each thyroid lobe were dissected individually and submitted for DNA extraction. Where available, concurrent blood samples were used for extraction of control DNA, and an additional 15 blood samples were obtained from the Clinical Pathology Service within the Faculty of Veterinary Science, University of Liverpool, from cats being treated for diseases other than $\mathrm{FH}$.

\section{DNA extraction}

Prior to extraction, individual tissue nodules were washed in two changes of $70 \%$ ethanol for $30 \mathrm{~min}$ each, to remove formalin from the tissue. Genomic DNA was extracted separately from each dissected nodule and blood sample, according to the manufacturer's instructions (DNeasy Tissue Extraction Kit; Qiagen, Venlo, the Netherlands), with the exception of proteinase $\mathrm{K}$ digestion, where the samples were digested for $2 \mathrm{~h}$ at $60^{\circ} \mathrm{C}$ followed by an overnight incubation of $42{ }^{\circ} \mathrm{C}$, both incubations with constant agitation. Both tissue and blood DNA samples were eluted in molecular-grade water (VWR International, Poole, Dorset, UK) in 100 and $400 \mu \mathrm{l}$ volumes respectively. Samples were extracted in batches and each batch included a DNA-negative control-extraction sample, where no tissue or blood was present. The quality of the extracted DNA was assessed by agarose gel electrophoresis.

\section{Primers}

Feline-specific oligonucleotide primers were designed within exon 10 of the feline TSHR gene to yield a $936 \mathrm{bp}$ PCR product covering codons 386-698 encompassing the transmembrane domain (MWG Biotech, Ebersberg, Germany). These primers were designed based on the available published genomic data (cat (GenBank accession no. AF218264); human (NM_000369); $\operatorname{dog}$ (X17146); pig (NM_214297); cow (NM_174206); sheep (Y13434); rat (NM_012888); mouse (NM_011648); African green monkey (AY1683990); Rhesus monkey (AY169400)) (Fig. 1). Primers were: FeTSHRF, 5'-ACTACACTGTG TGTGGAGGCAA-3', and FeTSHRR, 5'-TGCCAAA CTTGCTGAGCAGGATA-3'. To ensure the feline specificity of these TSHR primers, they were tested on human DNA obtained from blood, and under the same conditions as below, no amplification of the TSHR gene resulted (data not presented).

\section{PCR and sequence analysis}

PCR reactions of $50 \mu \mathrm{l}$ total volume were performed using the Qiagen Hot Start Kit (Qiagen). Each reaction contained $1 \mu$ l extracted DNA, $5 \mu 110 \times$ PCR buffer, $0.8 \mathrm{mM}$ dNTPs (Abgene, Epsom, Surrey, UK), $200 \mathrm{nM}$ forward/ reverse primer (MWG Biotech) and 1.25 units Taq polymerase, and the remaining volume was made up with molecular-grade water. Thermal cycle conditions for TSHR amplification were an initial denaturation of $95^{\circ} \mathrm{C}$ for $15 \mathrm{~min}$, followed by 40 cycles of $94^{\circ} \mathrm{C}$ for $30 \mathrm{~s}, 60^{\circ} \mathrm{C}$ for $30 \mathrm{~s}$ and $72{ }^{\circ} \mathrm{C}$ for $1 \mathrm{~min}$, with a final elongation step of $72{ }^{\circ} \mathrm{C}$ for $10 \mathrm{~min}$. Each PCR included a known positive control, a water negative control and the corresponding DNA-extraction-batch negative control. Amplified products were purified using the Qiagen Purification Kit (Qiagen) according to the manufacturer's instructions, eluted in $30 \mu \mathrm{l}$ molecular-grade water and sequenced using the PCR primers (Dundee Sequencing Service, University of Dundee, Dundee, Scotland, UK and Lark 
(A) Consensus

Cat

Human

Dog

Cow

Sheep

Pig

Mouse

Rat

AF Green Mon

Rhesus Monk
HYYVFFEEQE DEIIGFGQEL KNPQEETLQA FDSHYDYTVC G.NEDMVCTP

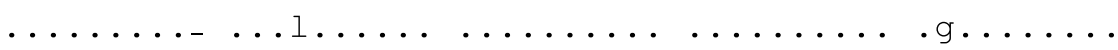

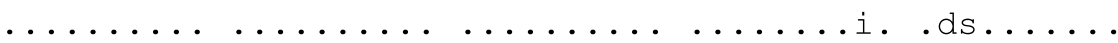

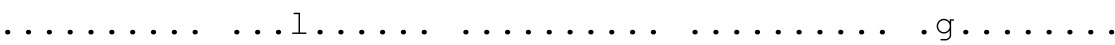

$\ldots \ldots \ldots \ldots \ldots \ldots q . \ldots \ldots \ldots \ldots \ldots$. $\ldots \ldots \ldots \ldots$

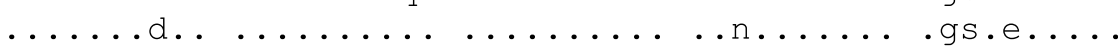

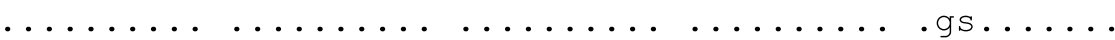

$\ldots \ldots \ldots \ldots$. vv ..................

$\ldots \ldots \ldots \ldots \ldots \ldots \ldots \ldots \ldots \ldots \ldots \ldots \ldots$

$\ldots \ldots \ldots \ldots \ldots \ldots \ldots \ldots \ldots \ldots \ldots \ldots \ldots \ldots \ldots$

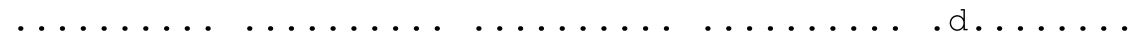

\begin{tabular}{|c|c|c|c|c|c|}
\hline Consensus & KSDEFNPCED & IMGYKFLRIV & VWFVSLLALL & GNVFVLLILL & TSHYKLTVPR \\
\hline Cat & $\ldots \ldots \ldots$ & $\ldots \ldots \ldots$ & $\ldots \ldots \ldots$ & $\ldots \ldots i \ldots$ & $\ldots \ldots \ldots$ \\
\hline Human & $\ldots \ldots \ldots$ & $\ldots \ldots \ldots$ & $\ldots \ldots \ldots$ & $\ldots \ldots \ldots$ & $\ldots n \ldots$ \\
\hline Dog & $\ldots \ldots$ & $\ldots \ldots \ldots$ & $\ldots \ldots \ldots$ & .....iv.. & $\ldots \ldots$ \\
\hline Cow & & $\ldots \ldots \ldots$ & $\ldots \ldots \ldots$ & $\ldots \ldots v \ldots$ & $\ldots \ldots \ldots$ \\
\hline heep & & $\ldots \ldots \ldots$ & $\ldots \ldots \ldots$ & $\ldots \ldots v \ldots$ & $\ldots \ldots$ \\
\hline Pig & & $\ldots r \ldots$ & $\ldots \ldots \ldots$ & $\ldots . . v \cdot \ldots$ & $\ldots$ \\
\hline Mouse & & $\ldots r \ldots$ & $\ldots \ldots \ldots$ & $\ldots i \ldots .$. & $\ldots \ldots \ldots$ \\
\hline Rat & $\cdots$ & $\ldots \ldots \ldots$ & $\ldots . . \mathrm{pm} .$. & $\ldots . . \mathrm{fv} \ldots$ & $\ldots \ldots \ldots$ \\
\hline AF Green Mon & $\ldots$ & $\ldots \ldots \ldots$ & $\ldots \ldots$ & $\ldots \ldots$ & $\ldots \ldots n \ldots$ \\
\hline nesus Monk & $\cdots$ & $\ldots \ldots \ldots$ & $\ldots \ldots \ldots$ & $\cdots$ & ...nn. \\
\hline
\end{tabular}

$\mathrm{S} 1$

Consensus

Cat

Human

Dog

Cow

Sheep

Pig

Mouse

Rat

AF Green Mon Rhesus Monk

S 2
FLMCNLAFAD FCMGMYLLLI ASVDLYTHSE YYNHAIDWQT GPGCNTAGFF

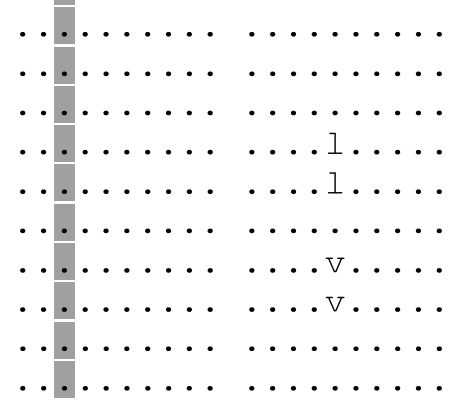

$\ldots \ldots \ldots$

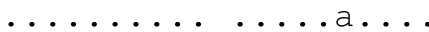

$\ldots \ldots \ldots \ldots \ldots$

$\ldots \ldots \ldots$

$\ldots . . . q^{. . .}$

$\ldots \ldots q$.

$\ldots \ldots q$.

$\ldots \ldots \ldots$

$\ldots . . . . t$

$\ldots \ldots$

........

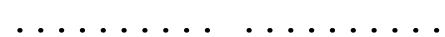

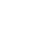

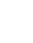

.........

Consensus
Cat
Human
Dog
Cow
Sheep
Pig
Mouse
Rat
AF Green Mon
Rhesus Monk

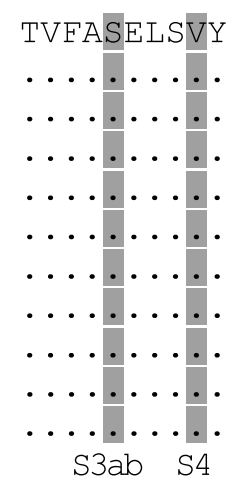

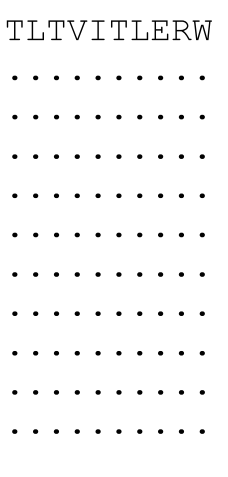

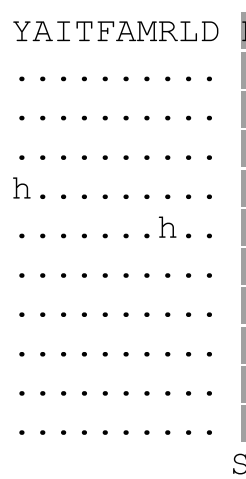

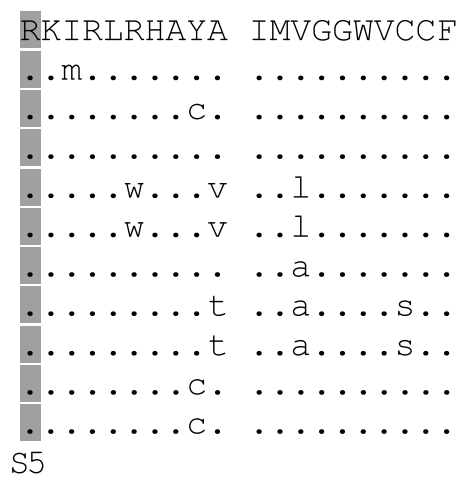


(B) Consensus

Cat

Human

Dog

Cow

Sheep

Pig

Mouse

Rat

AF Green Mon

Rhesus Monk
LLALLPLVGI SSYAKVSICL PMDTETPLAL AYIILVLLLN IVAFVIVCSC

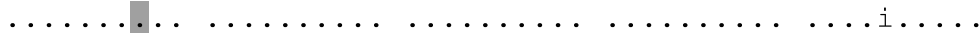

$\ldots \ldots \ldots \ldots \ldots \ldots \ldots \ldots \ldots \ldots \ldots \ldots$. . . . . . . .

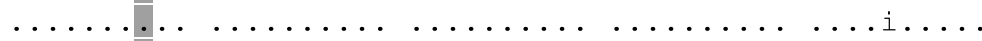

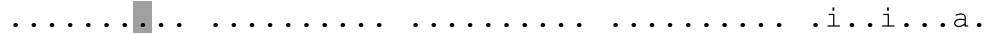

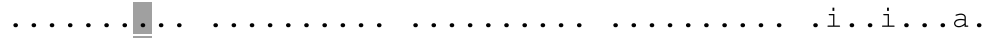

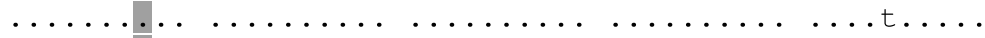

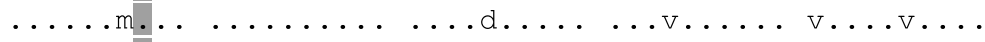

$\ldots \ldots m \ldots \ldots \ldots \ldots \ldots \ldots \ldots \ldots \ldots$

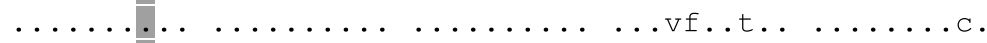

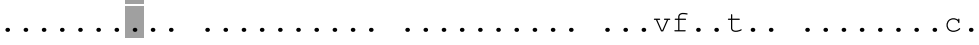

\begin{tabular}{|c|c|c|c|c|}
\hline Consensus & YVKIYITVRN & PQYNPGDKDT & KIAKRMAVLI FTDFMCMAPI & SFYALSALMN \\
\hline Cat & $\ldots \ldots \ldots$ & $\ldots$...... & $\ldots \ldots \ldots \ldots$ & $\ldots \ldots \ldots$ \\
\hline Human & h....... & $\ldots \ldots \ldots$ & $\ldots \ldots \ldots$ & $\ldots \ldots$... \\
\hline Dog & $\cdots \cdots \cdots$ & $\cdots \cdots \cdots$ & $\ldots \ldots \ldots$ & $\ldots \ldots \ldots$ \\
\hline Cow & $\ldots \ldots \ldots$ &.$h \ldots \ldots$ & $r \ldots \ldots \ldots$ & $\ldots \ldots \ldots$ \\
\hline Sheep & $\ldots \ldots \ldots$ & $. h \ldots .$. & $r \ldots \ldots$ & $\ldots \ldots \ldots$ \\
\hline Pig & $\ldots \ldots \ldots$ & $\ldots \ldots \ldots$ & $\ldots \ldots \ldots$ & $\ldots \ldots \ldots$ \\
\hline Mouse & $\ldots \ldots \ldots$ & $\ldots \ldots r \ldots$ & $\ldots \ldots \ldots$ & $\ldots \ldots$ \\
\hline Rat & $\ldots \ldots \ldots$ & $\ldots \ldots r \ldots$ & $\ldots \ldots \ldots$ & $\ldots \ldots \ldots$ \\
\hline Af Green Mon & $\ldots \ldots \ldots$ & & & $\ldots \ldots i l$. \\
\hline hesus Monk & $\ldots \ldots \ldots$ & & 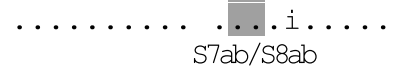 & ......il. \\
\hline Consensus & KPLITVTNSK & ILLVLFYPLN & SCANPFLYAI & ILLSKFGICK \\
\hline Cat & $\ldots \ldots \ldots$ & $\ldots \ldots \ldots$ & $\ldots t \ldots . .$. & $\ldots \ldots \ldots$ \\
\hline Human & $\ldots . . .$. & $\ldots \ldots \ldots$ & $\ldots \ldots \ldots$ & $\ldots \ldots \ldots$ \\
\hline Dog & $\ldots \ldots \ldots$ & $\ldots \ldots \ldots$ & $\cdots \cdots \cdots$ & $\ldots \ldots$ \\
\hline Cow & $\ldots \ldots \ldots$ & $\ldots \ldots \ldots$ & $\ldots \ldots \ldots$ & $m \ldots . .$. \\
\hline Sheep & $\ldots \ldots \ldots$ & $\ldots \ldots \ldots$ & $\ldots \ldots \ldots$ & $m \ldots \ldots$ \\
\hline Pig & $\ldots \ldots \ldots$ & $\ldots \ldots \ldots$ & $\ldots \ldots \ldots$ & $\ldots \ldots f$ \\
\hline Mouse & $\ldots \ldots \ldots$ & $\ldots \ldots \ldots$ & $\ldots \ldots \ldots$ & $\ldots \ldots$ \\
\hline Rat & $\ldots \ldots . . .9$ & $v \ldots \ldots$ & $\ldots \ldots \ldots$ & $\ldots \ldots 1$ \\
\hline AF Green Mon & $\cdots \cdots s \ldots$ & $\cdots \cdots \cdots$ & $\cdots \cdots \cdots$ & $\cdots \cdots \cdots$ \\
\hline resus Monk & ..s. & & & \\
\hline
\end{tabular}

Figure 1 Consensus sequence of the transmembrane domain of exon 10 of the TSHR gene showing the position of the 11 mutations/polymorphisms, S1-S8b (10 mis-sense, one silent) identified in thyroid adenomas and adenomatous hyperplastic nodules from hyperthyroid cats. Open boxes, primer-binding sites; dots show that a given amino acid is the same as the consensus sequence; a dash in the first line of the cat sequence indicates that Glu-360 in the human TSH receptor gene is not present in the equivalent published feline sequence. Therefore, beyond this point, the analogous human codon number is one greater than that of the feline TSHR. GenBank accession numbers: cat (AF218264); human (NM 000369); dog (X17146); pig (NM 214297); cow (NM 174206); sheep (Y13434); rat (NM 012888); mouse (NM 011648); African green monkey (AY1683990); Rhesus monkey (AY169400).

Technologies Sequencing Service, Lark Technologies, Takeley, Essex, UK). Forward and reverse sequences were aligned (MatchTool Navigator; Applied Biosystems), to produce a consensus sequence for each sample. Mutations were defined based on a comparison of this consensus sequence with the published feline TSHR gene sequence (AF218264) using programmes from the Wisconsin package (Genetics Computer Group; Devereaux et al. 1984). All codons were numbered according to the published feline sequence. The feline sequence has a deletion equivalent to codon 360 (glutamic acid) in the human TSHR. Therefore, beyond this point, the analogous human codon number is one greater than that of the feline TSHR.

\section{Results}

\section{Sample data}

Thyroid lobes were received from a total of 128 cats. Of these, 74 were excluded because the extracted DNA was of poor quality, due to inadequate or prolonged formalin fixation, and four samples were excluded because they were not diseased thyroid tissue (two lymph nodes, one blood clot and one normal thyroid lobe). From the remaining 50 cats, a total of 134 nodules and 19 blood samples were included. Tissue from one thyroid lobe was included from 48 cats, and from both lobes for the remaining two. Three of the 50 cats had no 
distinguishable nodules in the submitted thyroid tissue, so DNA was extracted from the whole lobe.

The 50 cats comprised 44 domestic short-hair (88\%), three domestic long-hair, one Siamese, one British Blue and 1 unknown breed. 25 (50\%) were male and $25(50 \%)$ female. The mean age for the cats was 13 years (range $7-17 \cdot 5$ years). Histopathology identified thyroid adenomas in 49 cases $(98 \%)$, and in eight $(16 \%)$ of these nodular adenomatous hyperplasia was also observed. A single adenoma was diagnosed in 32 cases (64\%), but adenomas were often lobulated, so that more nodules were identified grossly than adenomas were identified histologically. In lobes with more than one histologically confirmed adenoma, up to four individual tumours were identified. In one case, only nodular adenomatous hyperplasia was detected. Clinical details and histopathological diagnoses for the 50 cats in this study are summarized in Table 1.

\section{Genetic analysis of the TSHR gene}

Direct sequencing of the transmembrane domain of exon 10 of the TSHR gene produced $855 \mathrm{bp}$ of doublestranded consensus sequence, spanning codons 399-684. A consensus was identified only where both forward and reverse sequences agreed. When the consensus sequences were compared with the published sequence, a total of 168 polymorphisms were identified, affecting eight codons. 166 (99\%) were seen in both forward and reverse sequences. The remaining two were only seen in one sequence direction, and not the other. This was consistent over several repeats. These two mutations have been included in the results (see mutations S3b and S7a below).

In order to determine the reproducibility of the sequencing, DNA from six blood samples and 42 nodules from 20 cats were selected randomly, re-amplified and sequenced. In all cases, the same sequence, including heterozygous polymorphisms, was identified in these repeat consensus sequences as was detected in the first $\mathrm{PCR} /$ sequencing reaction (data not shown).

When the consensus sequences were compared with the published sequence, a total of 10 mis-sense mutations and one silent mutation were observed (Figs 2 and 3). Of the 134 nodules analysed, 66 had the same amino acid sequence as the published sequence, $47 \mathrm{had}$ one mis-sense mutation, 19 had two mis-sense mutations and two had three mis-sense mutations. The frequencies with which the mutations were identified are summarized in Table 2.

Of the 41 cats for which more than one nodule was available, 14 had nodules with different mutations (Table $3)$. In contrast, in the remaining 27 , all nodules from the same cats had the same sequence. 16 of these had either the published sequence or S1 polymorphism (see Figs 2 and 3 for details of mutations), four the S6 mutation either alone or with the S1 mutation, and the other seven had one or more of the other mis-sense mutations.

\section{Somatic mutations}

Nine somatic mutations were identified at six codon locations (Figs 2 and 3): Met-452 $\rightarrow$ Thr (S2), Ser-504 $\rightarrow$ Arg (two mutational forms, S3a and S3b), Val-508 $\rightarrow$ Arg (S4), Arg-530 $\rightarrow$ Gln (S5), Thr-631 $\rightarrow$ Ala (S7a), Thr$631 \rightarrow$ Phe (S7b), Asp-632 $\rightarrow$ Tyr (S8a) and Asp-632 $\rightarrow$ His (S8b). All were heterozygous.

35 of 134 nodules (26\%) in 17 of the 50 cats (34\%) had a mutation in the second transmembrane domain, resulting in Met-452 $\rightarrow$ Thr (S2) (Figs 2 and 3). Seven of these cats harboured this S2 mutation in all nodules (17 nodules in total). This was the most common mutation.

Two different mutations were located at codon 504 $(\mathrm{S} 3 \mathrm{a} / \mathrm{b})$, both of which resulted in Ser-504 $\rightarrow$ Arg. Each of these mutations was seen in one nodule from one cat, and S3b was only strongly visible in one sequencing direction. Mutation S4 (Val-508 $\rightarrow$ Arg) involved two altered nucleotides and was found in all three nodules taken from one cat only. Mutation S5 (Arg-530 $\rightarrow$ Gln), in the region of the second intracellular loop, was found in only two out of 134 nodules, both from the same cat. Two different mutations (S7a and S7b; Thr-631 $\rightarrow$ Ala and Thr$631 \rightarrow$ Phe) were located in the sixth transmembrane domain at codon 631, and each was found in only one nodule from a single cat, and S7a was only strongly visible in one sequencing direction. The final mis-sense mutation detected was also found in two different forms $(\mathrm{S} 8 \mathrm{a} / \mathrm{S} 8 \mathrm{~b})$ in codon 632. An aspartic acid residue was replaced with either a tyrosine (S8a) or a histidine residue (S8b). 10 out of 134 nodules $(7 \cdot 5 \%)$ in six out of 50 cats $(12 \%)$ harboured the Asp-632 $\rightarrow$ Tyr (S8a) mutation, and two cats had this mutation in all their nodules (four nodules in total). Only one nodule from one cat showed the S8b substitution.

Matched blood samples were available for seven cats whose thyroids harboured the S2 mutation, one cat whose thyroid harboured the S3b mutation, one with the S4 mutation and one with the S8a mutation. No matched blood samples were available for S3a, S5, S7a, S7b or S8b. None of these mutations (S2, S3a, S3b, S4, S5, S7a, S7b, $\mathrm{S} 8 \mathrm{a}$ and $\mathrm{S} 8 \mathrm{~b}$ ) were present in the blood samples from the hyperthyroid cats, nor in the 15 blood samples from cats not being treated for hyperthyroidism.

\section{Silent mutations/natural polymorphisms}

99 of the 134 hyperplastic nodules (74\%) from 37 of the 50 cats (74\%) harboured a silent substitution (S1) compared with published sequence (GAT/GAC, both aspartic acid) at codon 402, in the extracellular domain. This was heterozygous in 58 out of 99 nodules from 22 cats, and homozygous in 41 out of 99 nodules in 15 cats. All nodules from the 37 cats with this apparent silent mutation harboured the same sequence (Fig. 2). In addition, 15 of 19 control blood samples showed the 


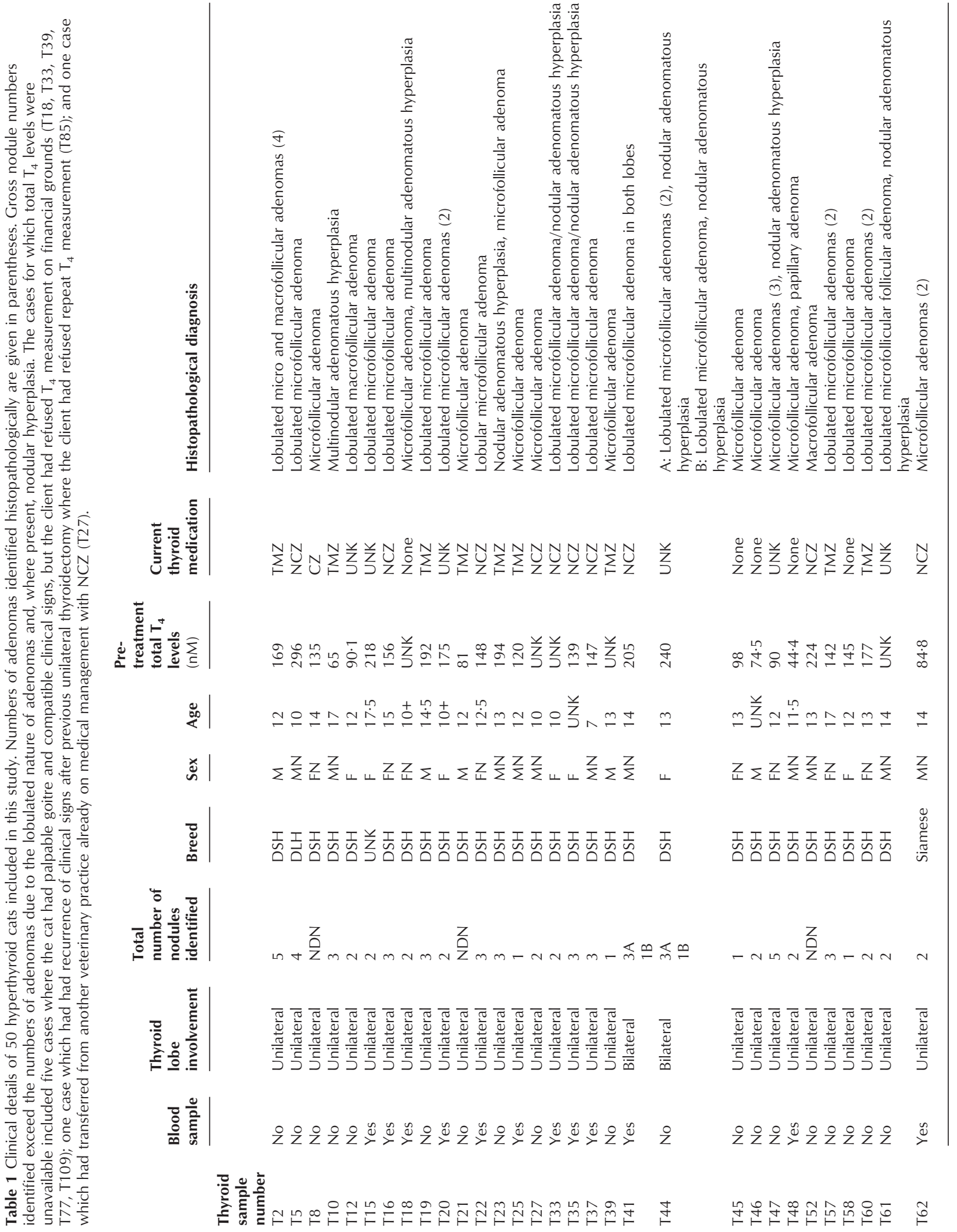



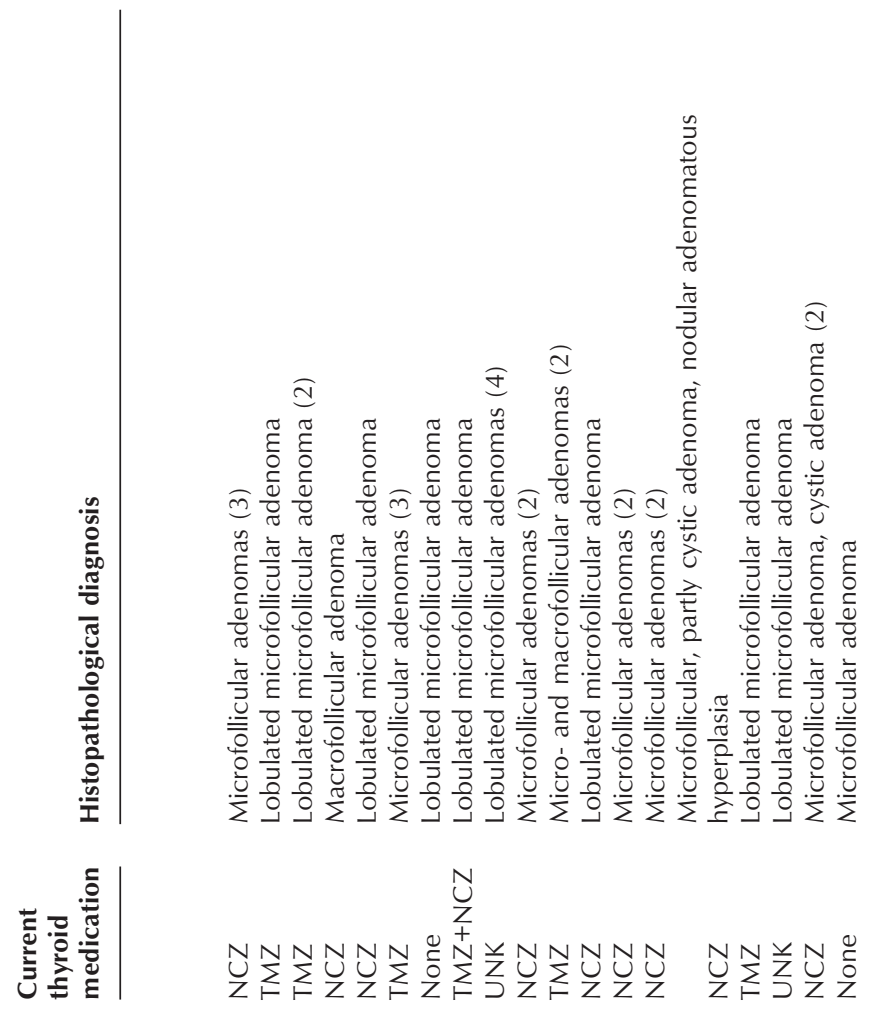

U
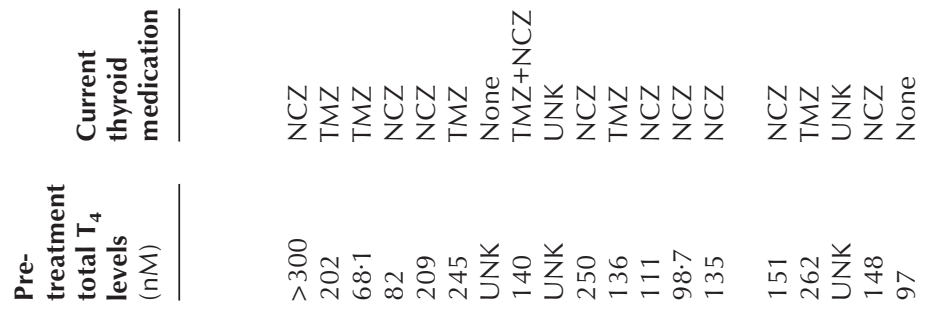

穴

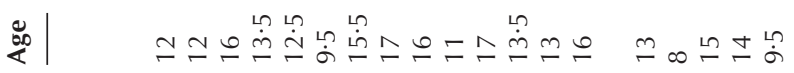

希

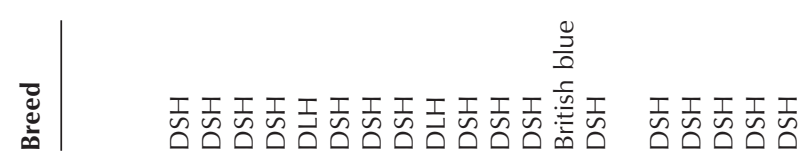

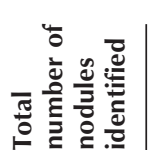

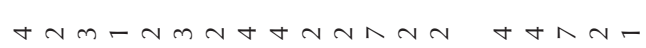
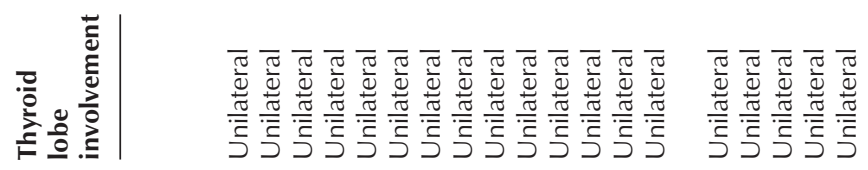

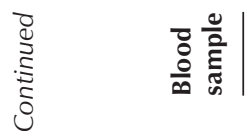

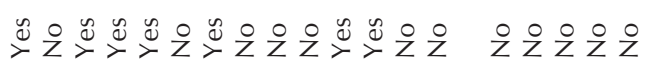

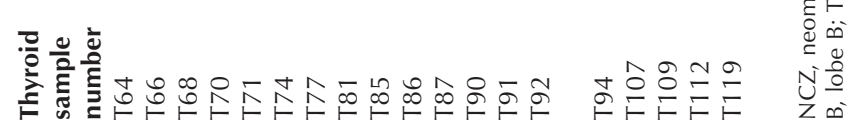




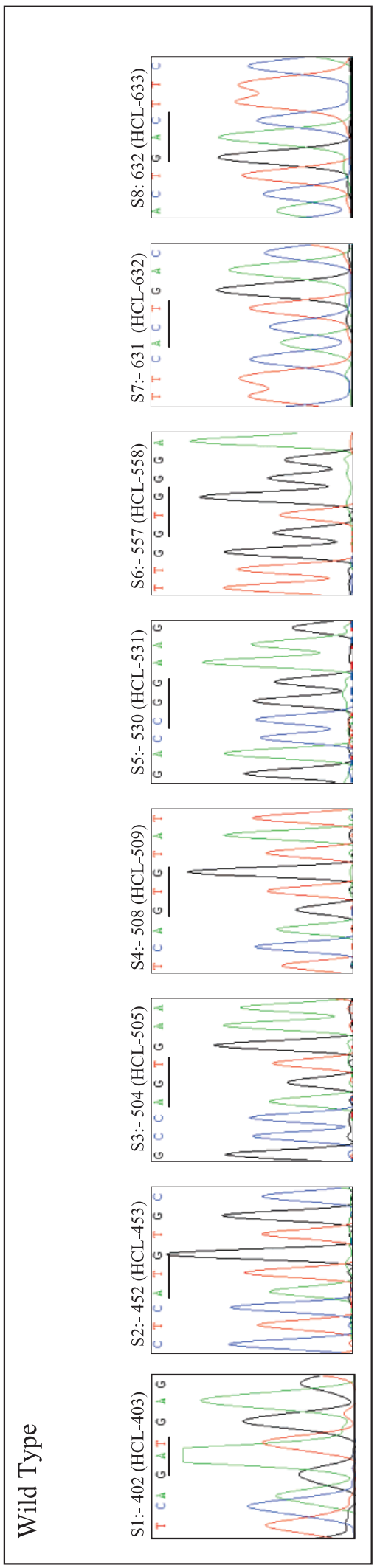

Journal of Endocrinology (2005) 186, 523-537

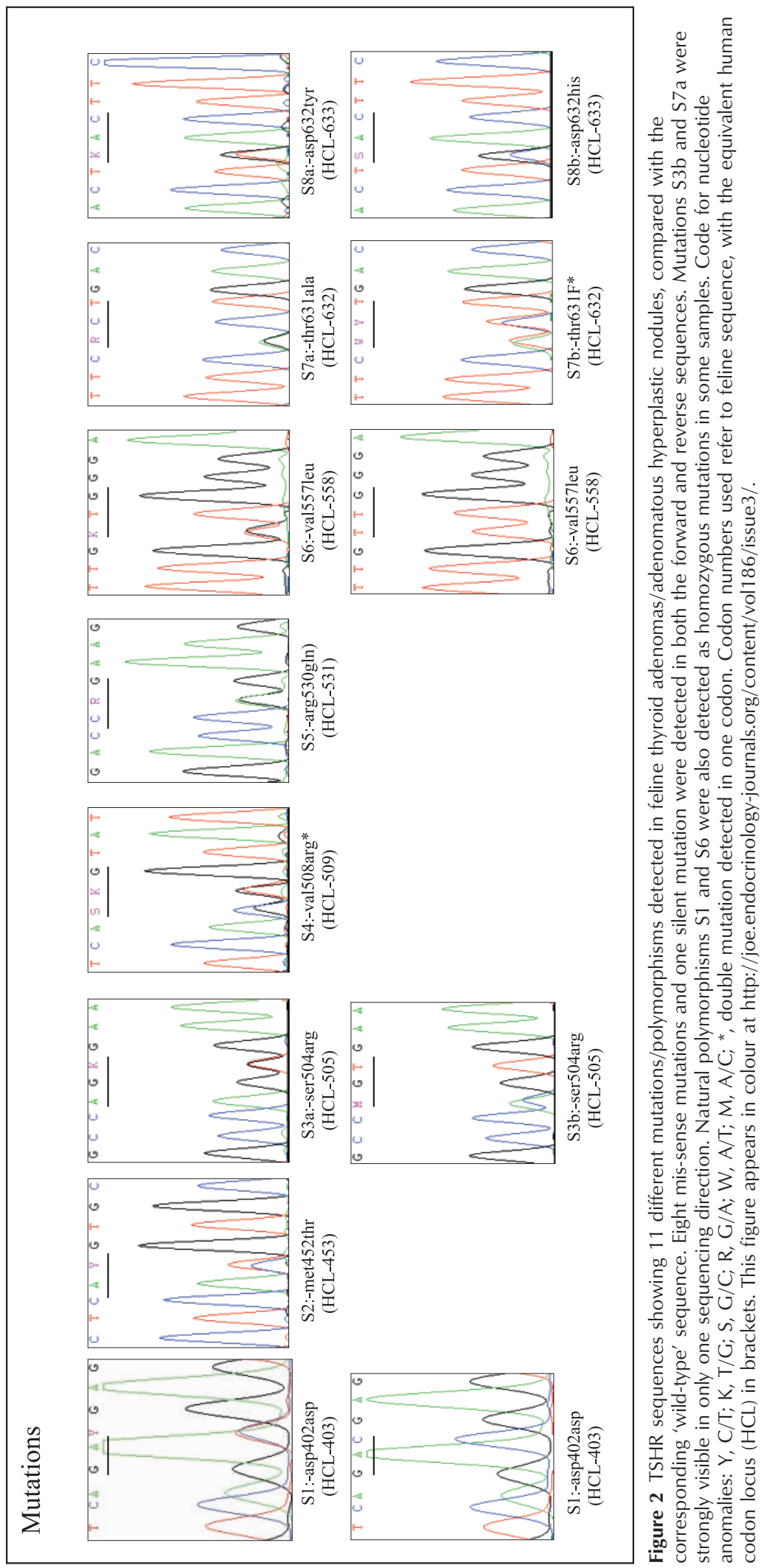

www.endocrinology-journals.org

Downloaded from Bioscientifica.com at 04/26/2023 07:34:21AM 


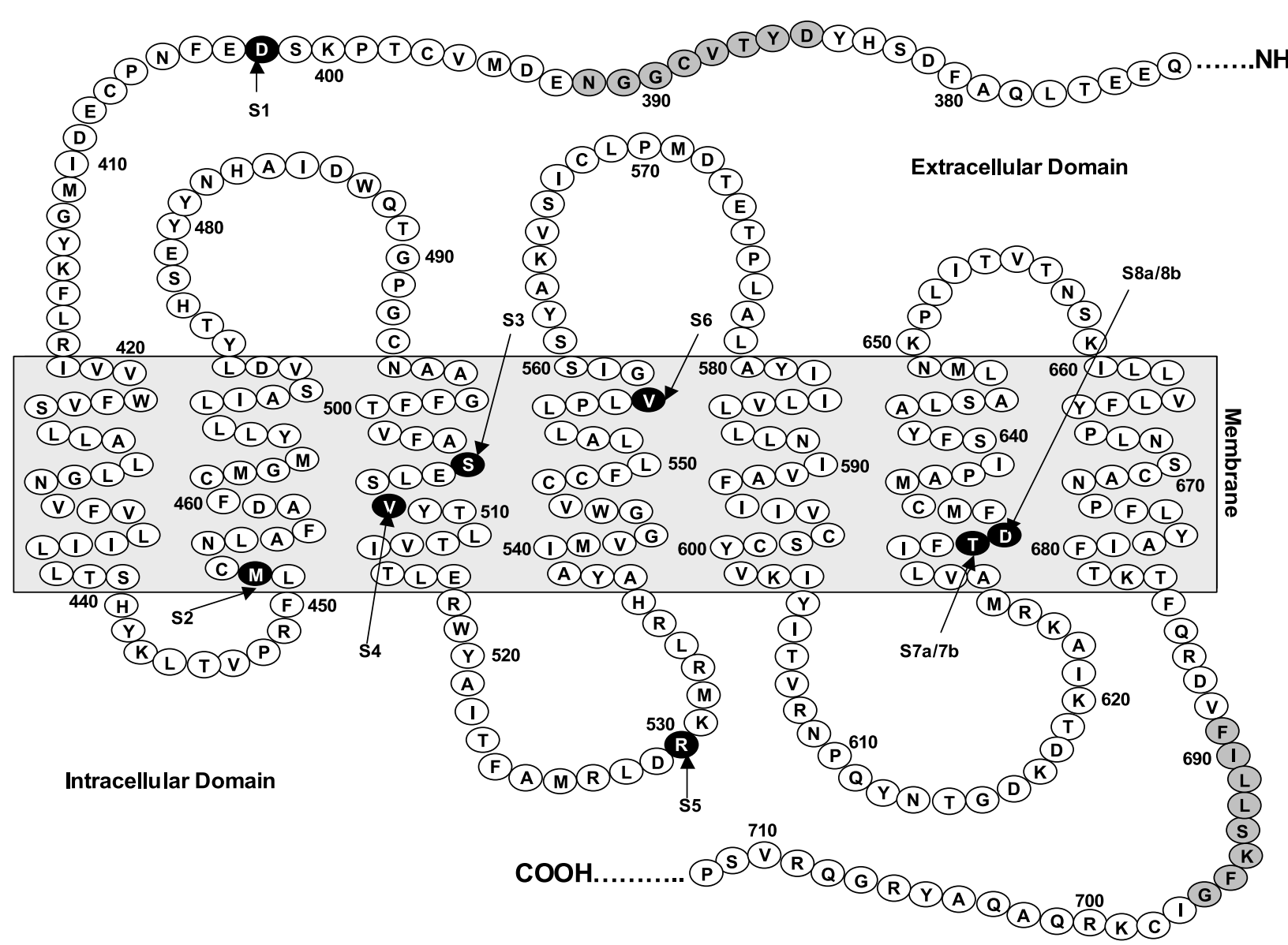

Figure 3 Schematic representation of the transmembrane domain of exon 10 of the feline TSHR showing the localization of mutations/polymorphisms found in this study (S1-S8b): affected codons are shown in black with white lettering. Dark-grey shading represents the site of primer binding. This illustration is derived from the equivalent human TSHR structure (Kopp 2001): the amino acid sequence presented is that of the feline TSHR. For all samples, $855 \mathrm{bp}$ of double-stranded DNA sequence were obtained spanning amino acids 399-684.

heterozygous/homozygous silent mutation S1, and all of these cats also had the same mutation in all thyroid nodules (41 out of 41). A similar polymorphism was detected in 12 of the 15 blood samples from control cats. This suggests that this is a normally polymorphic site in the feline TSHR, which is unlikely to be of functional significance.

A mutation in codon 557 of the fourth transmembrane domain (S6; Val-557 $\rightarrow$ Leu) was observed in 36 out of 134 nodules $(27 \%)$, in 13 out of 50 cats $(26 \%)$. However, this mutation was seen in all nodules taken from these 13 affected cats. In 32 nodules, from 12 cats, this mis-sense mutation was heterozygous. The remaining four nodules, three from one lobe and one from the contralateral lobe in the same cat, had a homozygous mutation. Interestingly, five of the 19 blood samples also harboured Val-557 $\rightarrow$ Leu (four heterozygous, one homozygous) and all nodules from the accompanying thyroid lobes from these five cats had this sequence in all nodules (17 out of 17). Blood samples were not available for eight cats where this mutation was detected in thyroid nodules, but all 19 nodules from these cats had the same mutation. In addition, two of the 15 blood samples from non-hyperthyroid cats revealed the same mutation. These findings suggest that this variation from the published sequence represents natural polymorphism.

\section{Discussion}

In this study, we have identified somatic mutations in the transmembrane region of exon 10 of the TSHR gene in thyroid adenomas and nodules of adenomatous hyperplasia from cats diagnosed with FH. To date, this is the largest number of samples recruited from hyperthyroid cats and analysed for TSHR genetic aberrations, and the first study specifically examining transformed/hypertrophic thyroid nodules. 


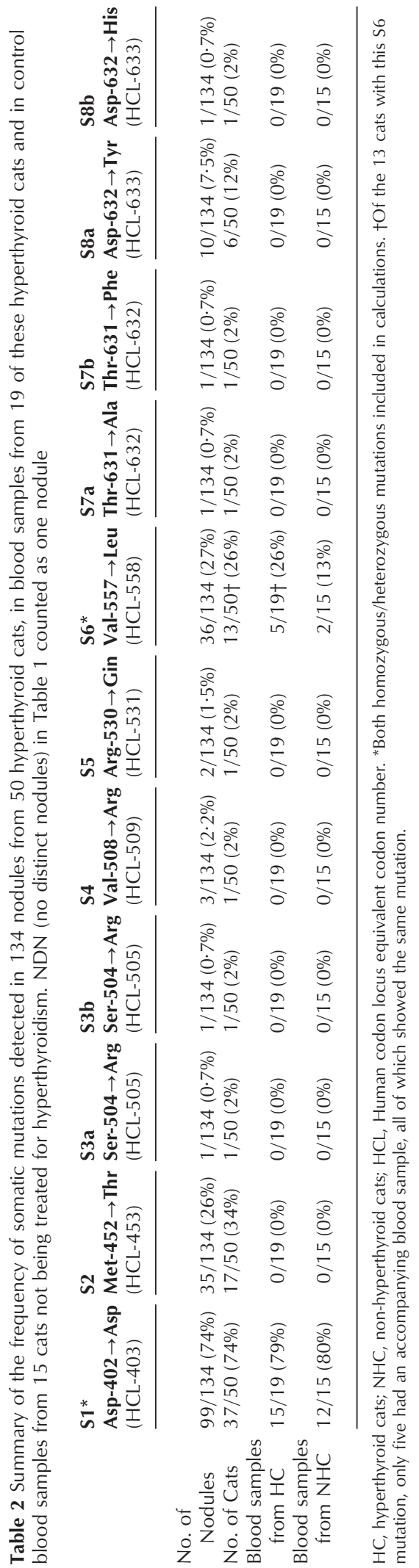




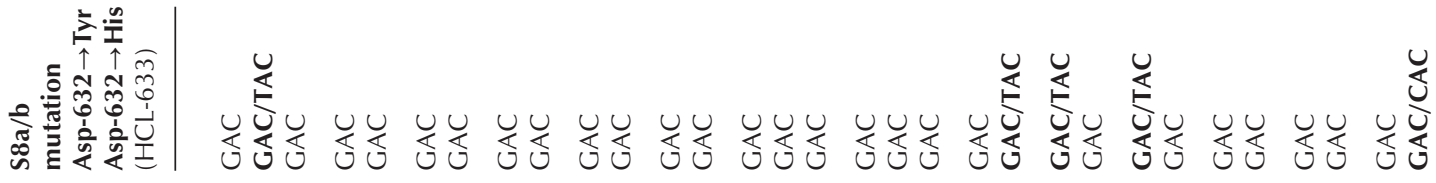

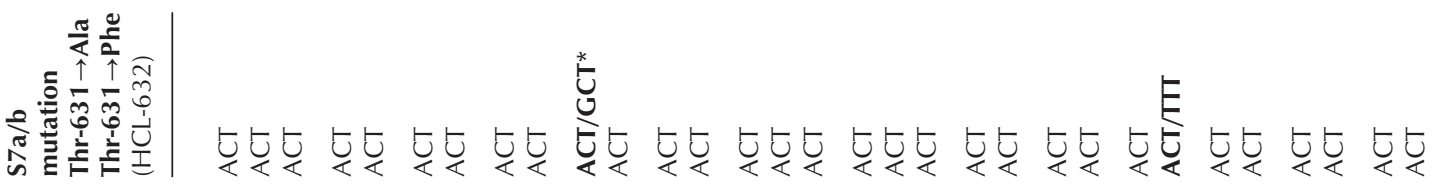

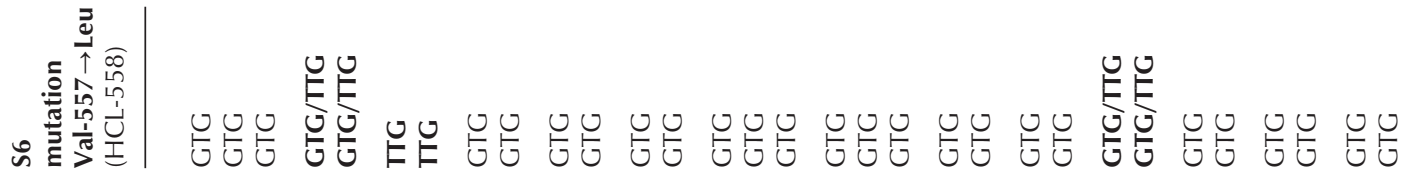

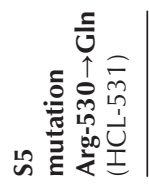

包

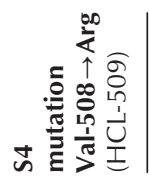

㫐㫐

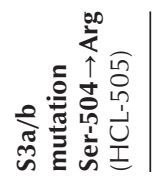

热

芯

U্ড

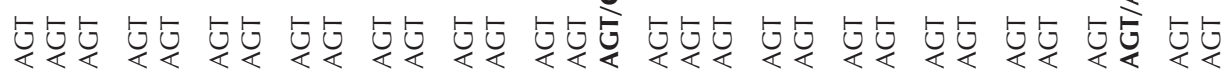

ஸู

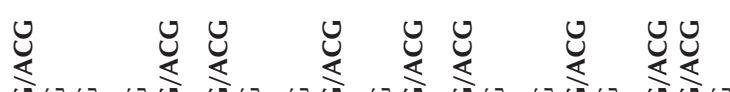

U)

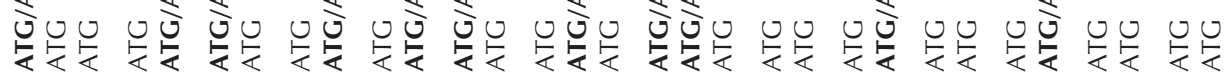

$\subseteq$

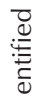

$\frac{0}{0}$

的产家全|

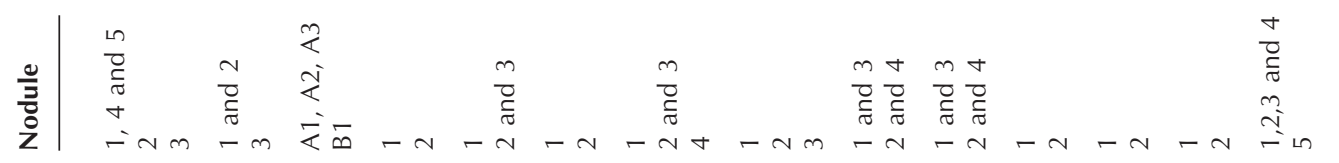

ङ 
A total of 11 mutations were detected in exon 10 of the TSHR gene (one silent, 10 mis-sense). Five of the 10 mis-sense mutations have previously been identified in human hyperthyroidism (Kosugi et al. 1994, Porcellini et al. 1994, Van Sande et al. 1995, De Roux et al. 1996, Russo et al. 1996, 1997, Spambalg et al. 1996, Tonacchera et al. 1996, 2000, Duprez et al. 1997a, Parma et al. 1997, Lavard et al. 1999, Mircescu et al. 2000, Trulzsch et al. 2001, Vanvooren et al. 2002, Fuhrer et al. 2003, Georgopoulos et al. 2003).

The most common somatic mutation detected was S2 (Met-452 $\rightarrow$ Thr), identified in $34 \%$ of cats. This is equivalent to the human Met-453 $\rightarrow \mathrm{Thr}$ mutation, which has been observed as both a germline and somatic (usually heterozygous) mutation in sporadic human hyperthyroidism, and in hyperplastic nodules and thyroid carcinoma (De Roux et al. 1996, Duprez et al. 1997a, Parma et al. 1997, Lavard et al. 1999, Mircescu et al. 2000, Trulzsch et al. 2001, Vanvooren et al. 2002, Georgopoulos et al. 2003). This mutation has not previously been reported in cats.

The mutation Ser-505 $\rightarrow$ Arg has been identified as a heterozygous germline mutation in familial human hyperthyroidism (Van Sande et al. 1995, Tonacchera et al. 1996). This is equivalent to S3a/b (Ser-504 $\rightarrow$ Arg), which has never been reported in feline studies. In the current study, cats with this mutation became hyperthyroid in middle age, which would suggest acquired rather than congenital disease. Unfortunately, there were no concurrent blood samples available for the cats bearing this anomaly; however, this mutation was not detected in the blood of non-hyperthyroid cats. Further work is required to determine the true nature of this mutation. Another mutation, Ser-505 $\rightarrow$ Asn, has been detected as a sporadic heterozygous germline mutation in four previous human studies (Schwab et al. 1996, Holzapfel et al. 1997b, Fuhrer et al. 1999, Wonerow et al. 2000), and also reported as a somatic heterozygous mutation in human hyperthyroidism (Trulzsch et al. 2001).

Mutations S4 and S5 have not been reported previously in either human or feline hyperthyroidism. The number of cats/nodules with these mutations was very small. The S4 (Val-508 $\rightarrow$ Leu) mutation was detected in all three nodules taken from one cat, which had a matching blood sample lacking this mutation, so may represent a somatic mutation. In human hyperthyroidism, Val-509 $\rightarrow$ Ala has been reported due to a heterozygous germline mutation (Duprez et al. 1994, Van Sande et al. 1995). Unfortunately, no blood sample was submitted from the single cat with the S5 (Arg-530 $\rightarrow$ Gln) mutation. Neither the S4 nor the S5 mutation was detected in non-hyperthyroid cat blood. The significance of these mutations is unclear, and functional studies are required.

The S6 (Val-557 $\rightarrow$ Leu) mutation/polymorphism has not been reported in human hyperthyroidism. It has, however, been identified in one of three cell lines estab- lished from hyperthyroid cats (Nguyen et al. 2002); these authors also concluded this mutation probably represents a simple polymorphism, since it has been shown to have no apparent effect on function.

Two different heterozygous mutations were located at codon 631 , Thr-631 $\rightarrow$ Ala (S7a) and Thr-631 $\rightarrow$ Phe (S7b). The equivalent mutation Thr-632 $\rightarrow$ Ala has been reported in human hyperthyroidism as a heterozygous somatic mutation in thyroid carcinomas (Spambalg et al. 1996) and hyperthyroid nodules (Tonacchera et al. 2000, Trulzsch et al. 2001, Vanvooren et al. 2002). Germline mutations are not reported. Neither mutation has been reported previously in FH. In our study, each mutation was only identified in one nodule from one cat, neither of which had an accompanying blood sample. Neither mutation was present in non-hyperthyroid blood samples. The S7b mutation, Thr- $631 \rightarrow$ Phe, has not been reported previously in either species.

The somatic heterozygous mutation Thr- $632 \rightarrow$ Iso is common in human hyperthyroid nodules/hyperfunctioning adenomas (Kosugi et al. 1994, Paschke et al. 1994, Porcellini et al. 1994, Russo et al. 1996, Duprez et al. 1997a, Fuhrer et al. 1997, Holzapfel et al. 1997a, Parma et al. 1997, Tonacchera et al. 1998a, 1998b, 1999, 2000, Trulzsch et al. 2001), and has also been reported in thyroid carcinoma (Spambalg et al. 1996). This mutation also occurs as a sporadic heterozygous germline mutation (Kopp et al. 1997a, Biebermann et al. 2000). A further somatic mutation, Thr- $632 \rightarrow$ Pro, has also been reported in autonomous thyroid nodules (Syrenicz et al. 1999). Thus the analogous feline mutations S7a and S7b may also be functionally significant, and the need for further investigation is indicated.

The remaining two mutations, Asp-632 $\rightarrow$ Tyr (S8a) and Asp-632 $\rightarrow$ His (S8b), have both been previously reported at human codon locus 633 in human hyperfunctioning adenomas/nodules and thyroid carcinomas as somatic, heterozygous mutations (Kosugi et al. 1994, Porcellini et al. 1994, Van Sande et al. 1995, Russo et al. 1996, 1997, Parma et al. 1997, Trulzsch et al. 2001, Fuhrer et al. 2003) but neither have been reported in $\mathrm{FH}$. Only one cat with the S8a or S8b mutation had a concurrent blood sample: DNA from this blood sample did not harbour either mutation, and neither mutation was detected in blood from non-hyperthyroid cats. Other identified somatic heterozygous mutations in human hyperthyroid nodules/hyperfunctioning adenomas at this codon location include Asp-633 $\rightarrow$ Glu (Kosugi et al. 1994, Porcellini et al. 1994, Van Sande et al. 1995, Fuhrer et al. 1997, Parma et al. 1997, Tonacchera et al. 1998b, 1999, 2000, Trulzsch et al. 2001) and Asp-633 $\rightarrow$ Ala (Parma et al. 1997).

Many more TSHR mutations have been detected in human hyperthyroidism, with at least 31 somatic and 17 germline mutations reported previously (Corvilain et al. 2001). All the mis-sense mutations detected in this study 
were found at codons that were completely conserved in the TSHR of other species (Fig. 1). In addition, of the mutations found in our study that have been reported previously, S2, S3a and S8a have been shown to enhance the constitutive activity of the TSH receptor (Kosugi et al. 1994, De Roux et al. 1996, Tonacchera et al. 1996, Porcellini et al. 1997). The activating effects of mutations analogous to S7a and S8b have not yet been determined (Russo et al. 1996, 1997, Spambalg et al. 1996, Parma et al. 1997, Tonacchera et al. 2000, Trulzsch et al. 2001, Vanvooren et al. 2002). However, in humans, other mutations in the S7a and S8b codons have been shown to be activating (Kosugi et al. 1994, Paschke et al. 1994, Porcellini et al. 1994, 1995, Van Sande et al. 1995).

Not all nodules taken from an individual animal or thyroid lobe showed the same mutations, with different mutations in different adenomas and hyperplastic nodules. A similar scenario has been found in human hyperthyroidism (Fuhrer et al. 1996, 2003, Duprez et al. 1997a, Holzapfel et al. 1997a, Parma et al. 1997, Tonacchera et al. 1998a, 2000). Both our study and previous human studies indicate the importance of nodule dissection from hyperplastic thyroid tissue when analysing for genetic mutations.

To our knowledge, there have only been three previously published molecular genetic studies of the TSHR gene in FH (Pearce et al. 1997, Nguyen et al.2002, Peeters et al. 2002). Pearce et al. (1997) did not identify any TSHR mutations in seven hyperthyroid cats, between codons 480 and 640 of exon 10. This region excludes areas where many mutations have been reported in humans, and the codons affected by S1 and S2. Peeters et al. (2002) investigated mutations mainly in the extracellular region of the TSHR gene spanning exons $1-9$, with only a small proportion of exon 10 being studied, including less than half of the transmembrane domain. They also identified the silent mutation/polymorphism S1. In addition, they identified a mutation in exon 5, Gly-139 $\rightarrow$ Ala, but this was not associated with disease. In both studies, DNA was extracted from the whole thyroid lobe, so that normal DNA from paranodular thyroid tissue may have masked any mutations present (Ferguson et al. 1990), and this technique also may reduce the chances of detecting multiple mutations in the same thyroid lobe. Finally, Nguyen et al. (2002) reported the S6 mutation (Val$557 \rightarrow$ Leu) in the exon 10 transmembrane domain in one of three thyroid cell lines obtained from autonomous nodules. This mutation probably represents a simple polymorphism since it has been shown to have no apparent effect on function. Our findings support this hypothesis, as this mis-sense mutation has been found in blood samples from both hyperthyroid and non-hyperthyroid cats in our study, with all tissue from the same cat always showing the same mutation.

As the current study does not include functional analyses, we can only suggest that the mutations are a probable cause of nodular proliferation and autonomous function. In addition, 22 cats had no detected mis-sense mutations in any nodules, and an additional four cats harboured only the S6 polymorphism thought not to be associated with the disease (Nguyen et al. 2002). Activating mutations may occur in exons 1-9 in these cats; however, there have been very few mutations detected in the extracellular region of the human TSHR gene (Duprez et al. 1997b, Kopp et al. 1997b, Parma et al. 1997, Gruters et al. 1998, Biebermann et al. 2000). Mutations may also occur in other genes involved in the signalling transduction pathway of the TSHR, and mutations have previously been found in a Gs $\alpha$ subunit (a protein coupled to the TSHR) gene, in both human and feline hyperthyroidism (Lyons et al. 1990, O’Sullivan et al. 1991, Du Villard et al. 1995, Russo et al. 1995, Parma et al. 1997, Murakami et al. 1999, Tonacchera et al. 1999, Trulzsch et al. 2001, Peeters et al. 2002, Vanvooren et al. 2002, Georgopoulos et al. 2003).

In summary, we have identified nine somatic mutations in exon 10 of the TSHR gene, affecting a total of four domains in the transmembrane region. Only one of these has previously been reported in vitro in cell cultures from hyperthyroid cats. Five of the somatic mutations have previously been identified in human hyperthyroidism. This study represents the first report of somatic mis-sense mutations in $\mathrm{FH}$, and further emphasises the complexity of the disease and its similarity to human TNG.

\section{Acknowledgements}

We would like to thank all the veterinary surgeons who kindly sent us thyroid lobes and to the owners of the cats for consenting to donate their cats' thyroids for the study, without which this investigation would not have been possible. We would also like to thank Dundee and Lark sequencing services for their technical support and Karen Coyne for help with the sequence analysis.

\section{Funding}

This work was supported by the Petplan Charitable Trust and the University of Liverpool, Faculty of Veterinary Science. The authors declare that there is no conflict of interest that would prejudice the impartiality of this work.

\section{References}

Biebermann H, Schoneberg T, Krude H, Gudermann T \& Gruters A 2000 Constitutively activating TSH-receptor mutations as a molecular cause of non-autoimmune hyperthyroidism in childhood. Langenbeck's Archives of Surgery 385 390-392.

Capen CC 2002 Tumor, hyperplasia and cysts of thyroid follicular cells. In Tumors in Domestic Animals, 4th edn, pp 638-650. Ed DJ Meuten. Ames, IO: Iowa State Press. 
Corvilain B, Sande JV, Dumont JE \&Vassart G 2001 Somatic and germline mutations of the TSH receptor and thyroid diseases. Clinical Endocrinology 55 143-158.

De Roux N, Polak M, Couet J, Leger J, Czernichow P, Milgrom E \& Misrahi M 1996 A Neomutation of the thyroid-stimulating hormone receptor in a severe neonatal hyperthyroidism. Journal of Clinical Endocrinology and Metabolism 81 2023-2026.

Deveraux J, Haeberli P \& Smithies O 1984 A comprehensive set of sequence analysis programs for the VAX. Nucleic Acids Research 12 387-395.

Duprez L, Parma J, Van Sande J, Allgeier A, Leclere J, Schvartz C, Delisle MJ, Decoulx M, Orgiazzi J, Dumont J et al. 1994 Germline mutations in the thyrotropin receptor gene cause non-autoimmune autosomal dominant hyperthyroidism. Nature Genetics 7 396-401.

Duprez L, Hermans J, Van Sande J, Dumont JE, Vassart G \& Parma J $1997 a$ Two autonomous nodules of a patient with multinodular goiter harbor different activating mutations of the thyrotropin receptor gene. Journal of Clinical Endocrinology and Metabolism 82 306-308.

Duprez L, Parma J, Costagliolo S, Herman J, Van Sande J, Dumont JE \& Vassart G $1997 b$ Constitutive activation of the TSH receptor by spontaneous mutations affecting the $\mathrm{N}$-terminal extracellular domain. FEBS Letters 409 469-474.

Du Villard JA, Schlumberger M, Wicker R, Caillou B, Rochefort P, Feunteun J, Monier R, Parmentier C \& Suarez HG 1995 Role of ras and gsp oncogenes in human epithelial thyroid tumorigenesis. Journal of Endocrinological Investigation 18 124-126

Ferguson DC \& Peterson ME 1990 In search of a cause for feline hyperthyroidism. Proceedings of 8th American College of Veterinary Internal Medicine (ACVIM) Forum 311 765-768.

Fuhrer D, Holzapfel HP, Wonerow P \& Paschke R 1996 Constitutively activating mutations of the thyrotropin receptor and thyroid disease. European Journal of Medical Research 1 460-464.

Fuhrer D, Holzapfel HP, Wonerow P, Scherbaum WA \& Paschke R 1997 Somatic mutations in the thyrotropin receptor gene and not in the $G_{s} \alpha$ protein gene in 31 toxic thyroid nodules. Journal of Clinical Endocrinology and Metabolism 82 3885-3891.

Fuhrer D, Mix M, Wonerow P, Richter I, Willgerodt H \& Paschke R 1999 Variable phenotype associated with Ser505 Asn-activating thyrotropin-receptor germline mutation. Thyroid 9 757-761.

Fuhrer D, Tannapfel A, Sabri O, Lamesch P \& Paschke R 2003 Two somatic TSH receptor mutations in a patient with toxic metastasising follicular thyroid carcinoma and non-functional lung metastases. Endocrine-related Cancer 10 591-600.

Georgopoulos NA, Sykiotis GP, Sgourou A, Papachatzopoulou A, Markou KB, Kyriazopoulou V, Papavassiliou AG \& Vagenakis AG 2003 Autonomously functioning thyroid nodules in a former iodine-deficient area commonly harbor gain-of-function mutations in the thyrotropin signaling pathway. European Journal of Endocrinology 149 287-292.

Gruters A, Schoneberg T, Biebermann H, Krude H, Krohn HP, Dralle H \& Gudermann T 1998 Severe congenital hyperthyroidism caused by a germ-line neo mutation in the extracellular portion of the thyrotropin receptor. Journal of Clinical Endocrinology and Metabolism 83 1431-1436.

Hegedus L 2004 The thyroid nodule. New England Journal of Medicine 351 1764-1771.

Hoenig M, Goldschmidt MH, Ferguson DC, Koch K \& Eymontt MJ 1982 Toxic nodular goitre in the cat. Journal of Small Animal Practice 23 1-12.

Holzapfel HP, Fuhrer D, Wonerow P, Weinland G, Scherbaum WA \& Pashke R 1997a Identification of constitutively activating somatic thyrotropin receptor mutations in a subset of toxic multinodular goiters. Journal of Clinical Endocrinology and Metabolism $\mathbf{8 2}$ 4229-4233.

Holzapfel HP, Wonerow P, Von Petrykowski W, Henschen M, Scherbaum WA \& Paschke R $1997 b$ Sporadic congenital hyperthyroidism due to a spontaneous germline mutation in the thyrotropin receptor gene. Journal of Clinical Endocrinology and Metabolism 82 3879-3884.

Holzworth J, Theran P, Carpenter JL, Harpster NK \& Todoroff RJ 1980 Hyperthyroidism in the cat: ten cases. Journal of American Veterinary Medical Association 276 345-353.

Kopp P 2001 The TSH receptor and its role in thyroid disease. Cellular and Molecular Life Sciences 58 1301-1322.

Kopp P, Jameson JL \& Roe TF 1997a Congenital nonautoimmune hyperthyroidism in a nonidentical twin caused by a sporadic germline mutation in the thyrotropin receptor gene. Thyroid 7 765-770.

Kopp P, Muirhead S, Jourdain N, Gu WX, Jameson JL \& Rodd C 19976 Congenital hyperthyroidism caused by a solitary toxic adenoma harbouring a novel somatic mutation (serine 281-isoleucine) in the extracellular domain of the thyrotropin receptor. Journal of Clinical Investigation 100 1634-1639.

Kosugi S, Shenker A \& Mori T 1994 Constitutive activation of cyclic AMP but not phosphatidylinositol signalling caused by four mutations in the transmembrane helix of the human thyrotropin receptor. FEBS Letters 356 291-294.

Lavard L, Sehested A, Brock Jacobsen B, Muller J, Perrild H, Feldt-Rasmussen U, Parma J \& Vassart G 1999 Long-term follow-up of an infant with thyrotoxicosis due to germline mutation of the TSH receptor gene (Met453 Thr). Hormone Research 51 43-46.

Leav I, Schiller AL, Rijnberk A, Legg MA \& Der Kinderen PJ 1976 Adenomas and carcinomas of the canine and feline thyroid. American Journal of Pathology 83 61-122.

Lyons J, Landis CA, Harsh G, Vallar L, Grunewald K, Feichtinger H, Duh QY, Clark OH, Kawasaki E, Bourne HR et al. 1990 Two G protein oncogenes in human endocrine tumors. Science 249 655-659.

Mircescu H, Parma J, Huot C, Deal C, Oligny LL, Vassart G \& Van Vliet G 2000 Hyperfunctioning malignant thyroid nodule in an 11-year old girl: pathologic and molecular studies. Journal of Pediatrics $137585-587$

Murakami M, Kamiya Y, Yanagita Y \& Masatomo M 1999 Gso mutations in hyperfunctioning thyroid adenomas. Archives of Medical Research 30 514-521.

Nguyen LQ, Arseven OK, Gerber H, Stein BS, Jameson JL \& Kopp P 2002 Cloning of the cat TSH receptor and evidence against an autoimmuno etiology of feline hyperthyroidism. Endocrinology 143 395-402.

O'Sullivan C, Barton CM, Staddon SL, Brown CL \& Lemoine NR 1991 Activating point mutations of the gsp oncogene in human thyroid adenomas. Molecular Carcinogenesis 4 345-349.

Pacini F, Burroni L, Ciuoli C, Cairano GD \& Guarino E 2004 Management of thyroid nodules: a clinicopathological evidence-based approach. European Journal of Nuclear Medicine and Molecular Imaging 31 1443-1449.

Parma J, Duprez L, Van Sande J, Hermans J, Rocmans P, Van Vliet G, Costagliola S, Rodien P, Dumont JE \& Vassart G 1997 Diversity and prevalence of somatic mutations in the thyrotropin receptor and $\mathrm{G}_{\mathrm{s}} \alpha$ genes as a cause of toxic thyroid adenomas. Journal of Clinical Endocrinology and Metabolism 82 2695-2701.

Paschke R, Tonacchera M, Van Sande J, Parma J \& Vassart G 1994 Identification and functional characterization of two new somatic mutations causing constitutive activation of the thyrotropin receptor in hyperfunctioning autonomous adenomas of the thyroid. Journal of Clinical Endocrinology and Metabolism 79 1785-1789.

Pearce SHS, Foster DJ, Imrie H, Myerscough N, Beckett GJ, Thoday KL \& Kendall-Taylor P 1997 Mutational analysis of the thyrotropin receptor gene in sporadic and familial feline thyrotoxicosis. Thyroid 7 923-927.

Peeters ME, Timmermans-Sprang EPM \& Mol JA 2002 Feline thyroid adenomas are in part associated with mutations in the $G_{s \alpha}$ gene and not with polymorphisms found in the thyrotropin receptor. Thyroid 12 571-575. 
Peter HJ, Gerber H, Studer H \& Smeds S 1985 Pathogenesis of heterogeneity in human multinodular goiter. A study on growth and function of thyroid tissue transplanted onto nude mice. Journal of Clinical Investigation 76 1992-2002.

Peterson ME \& Becker DV 1983 Spontaneous hyperthyroidism in the cat: an animal model for toxic nodular goitre. Proceedings of the American Thyroid Association's 59th Meeting T-31 (abstract).

Peterson ME, Randolph JF \& Mooney CT 1994 Endocrine diseases. In The Cat - Diseases and Clinical Management, 2nd edn, pp 1403-1506. Ed RG Sherding. New York: Churchill Livingstone.

Porcellini A, Ciullo I, Laviola L, Amabile G, Fenzi G \& Avvedimento VE 1994 Novel mutations of thyrotropin receptor gene in thyroid hyperfunctioning adenomas. Journal of Clinical Endocrinology and Metabolism 79 657-661.

Porcellini A, Ciullo I, Pannain S, Fenzi G \& Avvedimento E 1995 Somatic mutations in the VI transmembrane segment of the thyrotropin receptor constitutively activate cAMP signalling in the thyroid hyperfunctioning adenomas. Oncogene 11 1089-1093.

Porcellini A, Ruggiano G, Pannain S, Ciullo I, Amabile G, Fenzi G \& Avvedimento EV 1997 Mutations of thyrotropin receptor isolated from thyroid autonomous functioning adenomas confer TSH-independent growth to thyroid cells. Oncogene 15 781-789.

Russo D, Arturi F, Wicker R, Chazenbalk GD, Schlumberger M, Du Villard JAD, Caillou B, Monier R, Raport B, Filetti S \& Suarez HG 1995 Genetic alterations in thyroid hyperfunctioning adenoma. Journal of Clinical Endocrinology and Metabolism 80 1347-1351.

Russo D, Arturi F, Suarez HG, Schlumberger M, Du Villard JA, Crocetti U \& Filetti S 1996 Thyrotropin receptor gene alterations in thyroid hyperfunctioning adenomas. Journal of Clinical Endocrinology and Metabolism 81 1548-1551.

Russo D, Tumino S, Arturi F, Vigneri P, Grasso G, Pontecorvi A, Filetti S \& Belfiore A 1997 Detection of an activating mutation of the thyrotropin receptor in a case of an autonomously hyperfunctioning thyroid insular carcinoma. Journal of Clinical Endocrinology and Metabolism 82 735-738.

Spambalg D, Sharifi N, Elisei R, Gross JL, Mederiros-Neto G \& Fagin JA 1996 Structural studies of the thyrotropin receptor and $G_{s \alpha}$ in human thyroid cancers: Low prevalence of mutations predicts infrequent involvement in malignant transformation. Journal of Clinical Endocrinology and Metabolism 81 3898-3901.

Syrenicz A, Kurzawski G \& Ciechanowicz A 1999 The detection of somatic mutations of thyrotropin receptor gene in fine needle biopsy samples from thyroid nodules. Endocrine Regulations 33 95-101.

Thoday KL \& Mooney CT 1992 Historical, clinical and laboratory features of 126 hyperthyroid cats. The Veterinary Record 131 257-264.

Tonacchera M, Van Sande J, Cetani F, Swillens S, Schvartz C, Winiszewski P, Portmann L, Dumont JE, Vassart G \& Parma J 1996 Functional characteristics of three new germline mutations of the thyrotropin receptor gene causing autosomal dominant toxic thyroid hyperplasia. Journal of Clinical Endocrinology and Metabolism 81 547-554.

Tonacchera M, Vitti P, Agretti P, Giulianetti B, Mazzi B, Cavaliere R, Ceccarini G, Fiore E, Viacava P, Naccarato A et al. 1998a Activating thyrotropin receptor mutations in histologically heterogeneous hyperfunctioning nodules of multinodular goiter. Thyroid 8 559-564.

Tonacchera M, Chiovato L, Pinchera A, Agretti P, Fiore E, Cetani F, Rocchi R, Viacava P, Miccoli P \& Vitti P 1998b Hyperfunctioning thyroid nodules in toxic multinodular goiter share activating thyrotropin receptor mutations with solitary toxic adenoma. Journal of Clinical Endocrinology and Metabolism 83 492-498.

Tonacchera M, Vitti P, Agretti P, Ceccarini G, Perri A, Cavaliere R, Mazzi B, Naccarato AG, Viacava P, Miccoli P et al. 1999 Functioning and nonfunctioning thyroid adenomas involve different molecular pathogenetic mechanisms. Journal of Clinical Endocrinology and Metabolism 84 4155-4158.

Tonacchera M, Agretti P, Chiovato L, Rosellini V, Ceccarini G, Perri A, Viacava P, Naccarato AG, Miccoli P, Pinchera A et al. 2000 Activating thyrotropin receptor mutations are present in nonadenomatous hyperfunctioning nodules of toxic or autonomous multinodular goiter. Journal of Clinical Endocrinology and Metabolism $852270-2274$.

Trulzsch B, Krohn K, Wonerow P, Chey S, Holzapfel HP, Ackermann F, Fuhrer D \& Paschke R 2001 Detection of thyroid-stimulating hormone receptor and $G_{s} \alpha$ mutations: in 75 toxic thyroid nodules by denaturing gradient gel electrophoresis. Journal of Molecular Medicine 78 684-691.

Van Sande J, Parma J, Tonnachera M, Swillens S, Dumont J \& Vassart G 1995 Somatic and germline mutations of the TSH receptor gene in thyroid diseases. Journal of Clinical Endocrinology and Metabolism 80 $2577-2585$.

Vanvooren V, Uchino S, Duprez L, Costa MJ, Vandekerckhove J, Parma J, Vassart G, Dumont JE, Van Sande J \& Noguchi S 2002 Oncogenic mutations in the thyrotropin receptor of autonomously functioning thyroid nodules in the Japanese population. European Journal of Endocrinology 147 287-291.

Wonerow P, Chey S, Fuhrer D, Holzapfel HP \& Paschke R 2000 Functional characterization of five constitutively activating thytotropin receptor mutations. Clinical Endocrinology 53 461-468.

Yen PM 2000 Thyrotropin receptor mutations in thyroid diseases. Reviews in Endocrine and Metabolic Disorders 1 123-129.

Received 5 April 2005

Accepted 20 June 2005 